\title{
PENINGKATAN KEMANDIRIAN BELAJAR SISWA SMK PADA MATA DIKLAT TEKNOLOGI MEKANIK DENGAN METODE PROBLEM BASED LEARNING
}

\author{
FX. Wastono \\ SMK N 2 Pengasih Kulon Progo \\ E-mail: wastonofx@yahoo.co.id
}

\begin{abstract}
The objective of the study was to improve the students' learning independence for the subject of Mechanical Technology through Problem Based Learning. This study was categorized as a classroom action research. The subjects of study were the teacher and the grade X students of the Mechanical Engineering Department at SMK Negeri Kulon Progo. The data collection techniques used tests, observation and documentation. The validity of the study was proven by triangulation. The data analysis technique was qualitative descriptive. The results of the study revealed an improvement of the students' learning independence indicated by (1) the scores of the test satisfying the minimum mastery criterion increased from $25 \%$ to $70 \%$ (2) the increase of the students' responsibility from $37 \%$ to $72 \%$ (3) The increase of the students' learning discipline from $32 \%$ to $67 \%$ (4) The increase of the students 'creativity and activeness from $14 \%$ to $65 \%$. It is noted that Problem Based Learning can improve the students' learning independence and achievement.
\end{abstract}

Keywords: Achievement, Independence, Problem Based Learning

\begin{abstract}
ABSTRAK
Penelitian ini bertujuan untuk meningkatkan kemandirian siswa dalam hasil belajar Mata Diklat Teknologi Mekanik (MDTM) melalui metode problem based learning. Metode penelitian menggunakan Penelitian Tindakan Kelas (PTK), dengan subyek peneliti dan guru kelas X SMK Negeri di Kulon Progo jurusan Teknik Pemesinan. Metode pengumpulan data dengan cara tes, observasi, dan dokumentasi. Validasi data penelitian menggunakan teknik trianggulasi, secara deskriptif kualitatif. Hasil penelitian menunjukkan adanya peningkatan kemandirian hasi belajar MDTM siswa kelas X TM1 SMK Negeri di Kulon Progo. Hasil ini dapat dilihat dari 1) hasil tes memenuhi kriteria ketuntasan minimal (KKM) sebelum tindakan $25 \%$ dan setelah tindakan $70 \%$ 2) mampu bertanggung jawab atas permasalahan yang ada sebelum tindakan $37,6 \%$ dan setelah tindakan 72\% 3) mampu disiplin dalam proses pembelajaran sebelum tindakan $32 \%$ dan setelah tindakan $67 \%$ 4) mampu aktif dan kreatif sebelum tindakan $14 \%$ dan setelah tindakan $65 \%$. Penggunaan metode problem based learning dapat meningkatkan kemandirian dan hasil belajar pada mata diklat Teknologi Mekanik siswa kelas X SMK Negeri di Kulon Progo.
\end{abstract}

Kata Kunci: Hasil Belajar, Kemandirian, Problem Based Learning

\section{PENDAHULUAN}

Sekolah Menengah Kejuruan (SMK) sebagai bentuk satuan penyelenggara pendidikan menengah kejuruan. SMK merupakan lembaga pendidikan yang berorientasi pada pembentukan kecakapan hidup. Kecakapan hidup yaitu melatih peserta didik untuk menguasai keterampilan yang dibutuhkan oleh dunia kerja dan industri. SMK memberikan pendidikan tentang ketrampilan dan kewirausahaan, serta membentuk kecakapan hidup (life skill). Siswa SMK lebih ditekankan untuk melakukan praktik sehingga siswa perlu mempunyai kemandirian dan pengalaman secara langsung sebagai bekal memasuki dunia kerja dan industri.

Kemandirian belajar merupakan salah satu hal yang penting dalam suatu proses belajar mengajar. Kemandirian diperlukan agar mempunyai rasa tanggung jawab dalam mengatur dan mendisiplinkan diri. Haris Mujiman (2007) menjelaskan bahwa kemandirian belajar 
adalah kegiatan belajar aktif yang didorong oleh niat dan motif untuk menguasai suatu kompetensi guna mengatasi suatu masalah, dan dibangun dengan bekal pengetahuan atau kompetensi yang telah dimiliki. Kemandirian dalam belajar dapat diartikan sebagai aktivitas proses belajar mengajar dan berlangsungnya lebih didorong oleh kemauan sendiri, pilihan sendiri dan tanggung jawab sendiri dari proses belajar mengajar. Siswa dikatakan telah mampu belajar secara mandiri apabila telah mampu melakukan tugas belajar atas inisiatif sendiri tanpa ketergantungan dengan orang lain.

Berdasarkan pengamatan lapangan diketahui bahwa kemandirian siswa belajar mata diklat Teknologi Mekanik di SMK Negeri di Kulon Progo kelas X Jurusan Teknik Pemesinan masih rendah. Setelah melakukan observasi pendahuluan ditemukan permasalahan: 1) bertanggung jawab atas permasalahan yang ada sebesar $17 \%$, 2) mampu disiplin dalam proses belajar mengajar sebesar $32 \%$, mampu untuk aktif dan kreatif sebesar 14\%. Rendahnya kemandirian belajar siswa ini disebabkan karena siswa menganggap mata diklat Teknologi Mekanik merupakan mata diklat yang materinya cukup banyak sehingga siswa harus membuat tugas mandiri tentang materi Teknologi Mekanik.Selain itu saat mengerjakan job sheet (praktik) yang diberikan guru, banyak siswa yang tidak percaya diri pada kemampuan dirinya sendiri.

Untuk meningkatkan kemandirian belajar mata diklat Teknologi Mekanik yaitu dengan metode Problem Based Learning. Metode Problem Based Learning merupakan sebuah metode yang mudah, guna memperoleh partisipasi kelas yang keseluruhan dan tanggung jawab secara individu. Metode ini memberikan kesempatan pada setiap siswa untuk bertindak sebagai seorang guru terhadap siswa lain. Dengan metode Problem Based Learning ini siswa yang selama ini tidak aktif akan ikut serta dalam proses belajar mengajar secara aktif.

Penelitian ini mempunyai tujuan untuk meningkatkan kemandirian siswa dalam mata diklat Teknologi Mekanik dan memiliki tujuan khusus yaitu untuk meningkatkan kemandirian dan hasil prestasi belajar mata diklat Teknologi Mekanik dengan menggunakan metode Problem Based Learning di SMK Negeri Kulon Progo.

Sutama (2010: 13) menjelaskan bahwa tes adalah seperangkat rangsangan (stimulasi) yang diberikan kepada seorang dengan maksud untuk mendapatkan jawaban-jawaban yang dijadikan penetapan skor angka, adapun jenis tes dalam penelitian ini meliputi tes prestasi belajar dan tes kecerdasan.

Sutama (2010: 35) menjelaskan bahwa dokumentasi digunakan untuk memperoleh data sekolah dan identitas siswa antara lain seperti nama siswa, nomor induk siswa dengan melihat dokumentasi yang ada disekolah. Dokumentasi dalam penelitian ini dilakukan dengan cara melakukan observasi dengan guru mata diklat Teknologi Mekanik dan pengamatan lansung disekolah.

Instrumen dikatakan valid apabila mampu mengukur apa yang diinginkan dari variabel yang diteliti secara tepat (Arikunto, 2011). Penelitian ini menggunakan kisi-kisi yang terdapat variabel yang diteliti, indikator sebagai tolak ukur dan nomor bukti (item) pertanyaan atau pernyataan yang telah dijabarkan dari indikator. Analisis data penelitian ini dilakukan secara deskripsi kualitatif dengan metode alur. Alur yang dilalui meliputi reduksi data, penyajian data, penarikan kesimpulan atau verifikasi yang diungkapkan oleh Miles dan Huberman (Sugiyono, 2008: 91). Penyajian data dilakukan dengan cara menyusun data yang relevan sehingga menjadi informasi yang dapat disimpulkan memiliki makna tertentu, sedangkan verifikasi data dilakukan secara bertahap untuk memperoleh derajat kepercayaan tinggi.

Berdasarkan hasil penelitian terdahulu yang dilakukan oleh Cendikia Rakhmad Darmawan (2014) disimpulkan bahwa ada pengaruh peningkatan kemandirian dan hasil belajar Matematika melalui strategi pembelajaran Project Based Learning (PBL) ditinjau dari kemandirian belajar siswa. Chaplin (Hayati, 2008: 36) 
menerangkan kemandirian berarti keadaan pengaturan diri. Sejalan pengertian diatas Ryan dan Lyynch (Nurrani, 2009: 28) mengemukakan bahwa "autonomy is an ability regulate one's behavior to select and guide one's decision and actions. Without undue control from parent of dependence on parents". Berdasarkan penelitian terdahulu tersebut, terdapat perbedaan penelitian dengan yang peneliti lakukan yaitu jenis mata diklat pembelajaran dan pokok bahasan sedangkan kesamaanya adalah satu fokus yang diteliti adalah kemandirian belajar siswa.

\section{METODE}

Jenis penelitian ini adalah Penelitian Tidakan Kelas (PTK) atau Classroom Action Research (CAR) yang dilakukan secara kolaborasi antara guru mata dklat Teknologi Mekanik dan peneliti. Aqip (2009: 19) menjelaskan penelitian tindakan kelas adalah penelitian yang dilakukan oleh guru di kelas atau sekolah tempat mereka mengajar dengan penekanan pada penyempurnaan atau peningkatan proses dan praktik pembelajaran. PTK ditandai dengan adanya proses perbaikan terus menerus sehingga tercapainya tujuan dari penelitian tersebut. Proses perbaikan dilakukan pada setiap siklus yang direncanakan oleh peneliti.

Tempat penelitian ini dilaksanakan di SMK Negeri di Kulon Progo. Alasan peneliti mengadakan penelitian di SMK Kulon Progo yaitu jumlah siswa representatif untuk diteliti, memiliki hasil prestasi belajar mata diklat Teknologi Mekanik yang rendah, kemandirian dalam mengerjakan tugas yang rendah dan tanggung jawab individu yang rendah. Penelitian ini dilaksanakan mulai bulan Januari 2015 sampai bulan Mei 2015 yang dibagi menjadi 2 siklus. Untuk lebih jelasnya tahaptahap kegiatan penelitian dapat disajikan sebagai berikut: 1) tahap persiapan bulan Januari tahun 2015 , 2) tahap pelaksanaan bulan Februari sampai bulan April tahun 2015 dan 3) tahap penyelesaian bulan Mei tahun 2015
Subyek penelitian ini adalah siswa dan guru SMK di Kulon Progo tahun pelajaran 2014/2015. Siswa yang menjadi subyek penerima tindakan ini yaitu siswa kelas X TM 1 jurusan Teknik Pemesinan.

Obyek penelitian yang akan diteliti adalah kemandirian dan hasil belajar mata diklat Teknologi Mekanik siswa kelas X jurusan Teknik Pemesinan tahun 2014/2015 melalui metode Problem Based Learning. Kompetensi yang digunakan dalam penelitian ini adalah kemampua menggunakan perkakas tangan.

Penelitian ini merupakan tindakan kelas secara kolaboratif dilakukan oleh penelitian guru Teknologi Mekanik yang bersifat praktis, situasional, kondisional dan contextual berdasarkan pemahaman sehari-hari. Peneliti bersama guru mata diklat Teknologi Mekanik berusaha memperoleh hasil yang optimal melalui cara dan prosedur yang dinilai efektif sehingga memungkinkan adanya tindakan berulang-ulang dengan revisi untuk meningkatkan kemandirian dan hasil belajar mata diklat Teknologi Mekanik. Guru Teknologi Mekanik dilibatkan sejak (a) wawancara awal, (b) rencana tindakan, (c) pelaksanaan tindakan, (d) observasi, (e) refleksi, (f) evaluasi, dan (g) simpulan.

Penelitian ini dilakukan secara deskriptif kualitatif. Sumber data yang utama adalah peneliti yang melakukan tindakan dan siswa yang menerima tindakan, serta sumber data berupa dokumentasi. Pengambilan data dilakukan dengan observasi, tes, dokumentasi, catatan lapangan, dan review.

Peneliti melakukan observasi dengan cara mengadakan pengamatan secara langsung. Observasi dilakukan di SMK di Kulon Progo kelas X Jurusan Teknik Pemesinan yang menjadi obyek penelitian untuk mendapatkan gambaran secara langsung tentang kegiatan belajar mengajar mata diklat di dalam kelas maupun di dalam bengkel.

Instrumen penelitian dikembangkan oleh peneliti bersama guru mata diklat Teknologi Mekanik. Dalam melakukan observasi peneliti menggunakan pedoman observasi yang terbagi menjadi 3 bagian yaitu observasi proses guru 
dalam mengajar, observasi proses siswa belajar, dan keterangan tambahan yang berkaitan dengan proses belajar mengajar yang belum tercapai.

Keabsahan data menunjukkan bahwa data yang diperoleh adalah benar, dicek kepada beberapa pihak hasilnya hampir sama. Keabsahan data diperoleh melalui trianggulasi data yaitu teknik pemeriksaan keabsahan data yang memanfaatkan sesuatu yang lain diluar data untuk keperluan pengecekan atau sebagai pembanding terhadap data tersebut (Meleong, 2006: 106).

\section{HASIL DAN PEMBAHASAN}

Berdasarkan proses belajar mengajar secara keseluruhan sampai tindakan putaran II, perilaku siswa berdasarkan permasalahan yang diangkat dalam penelitian ini mengalami perubahan yang positif. Hasil penelitian pada putaran II diperoleh simpulan bahwa tindakan belajar yang diambil telah berhasil meningkatkan kemandirian dan hasil belajar mata diklat Teknologi Mekanik siswa kelas X SMK Negeri di Kulon Progo. Data sebelum tindakan kelas mengenai peningkatan kemandirian dan hasil belajar mata diklat Teknologi Mekanik siswa dengan menggunakan metode problem based learning bahwa kemandirian dan hasil belajar siswa masih rendah, nilai siswa belum memenuhi kriteria ketuntasan minimum KKM $\geq 7.5$ sebanyak 8 siswa yaitu sebesar $25 \%$, banyaknya siswa yang mampu bertanggung jawab atas permasalahan yang ada sebanyak 12 siswa atau sebesar 37\%, mampu disiplin dalam proses proses pembelajaran sebanyak 10 siswa atau sebesar $32 \%$, dan mampu untuk aktif dan kreatif sebanyak 4 siswa atau sebesar 14\%.

Data peningkatan kemandirian dan hasil belajar mata diklat Teknologi Mekanik menggunakan metode Problem Based Learning dari hasil soal mandiri I pada putaran I siswa yang mendapat nilai diatas $\mathrm{KKM} \geq 75$ sebanyak 15 siswa atau $46 \%$, banyaknya siswa yang mampu bertanggung jawab atas permasalahan yang ada sebanyak 15 siswa atau sebesar 46\%, mampu disiplin dalam proses proses belajar mengajar sebanyak 14 siswa atau sebesar 43\%, dan mampu untuk aktif dan kreatif sebanyak 11 siswa atau sebesar $34 \%$.

Putaran II banyaknya nilai siswa yang memenuhi $K K M \geq 75$ sebanyak 21 siswa atau sebesar $65 \%$, banyaknya siswa yang mampu bertanggung jawab atas permasalahan yang ada sebanyak 23 siswa atau sebesar $72 \%$, mampu disiplin dalam proses belajar mengajar sebanyak 21 siswa atau sebesar $67 \%$, dan mampu untuk aktif dan kreatif sebanyak 20 siswa atau sebesar 65\%. Peningkatan hasil belajar siswa dapat dilihat dari meningkatnya indikator kemandirian dan hasil belajar yang peneliti buat dari sebelum penelitian sampai penelitian tindakan terakhir.

Hasil belajar Teknologi Mekanik siswa sebelum dilaksanakan tindakan kelas masih rendah ini terbukti dengan hasil tes pendahuluan yang memenuhi $\mathrm{KKM} \geq 75$ hanya 6 siswa. Solusi yang digunakan adalah dengan metode pembelajaran Problem Based Learning sehingga siswa tertarik juga dapat mengkaitkan pelajaran dengan kehidupan sehari-hari.Putaran I yang indikator-indikator kemandirian belajar Teknologi Mekanik siswa sudah mulai terlihat dibanding sebelum tindakan. Evaluasi atau perbaikan pada putaran I yang diterapkan pada putaran II membawa dampak perubahan yang positif, persentase indikator-indikator kemandirian Teknologi Mekanik semakin meningkat secara signifikan dan sesuai dengaan yang diharapkan.

Hasil penelitian tersebut mendukung hipotesis bahwa dengan menggunakan strategi Problem Based Learning dapat meningkatkan kemandirian dan hasil belajar Teknologi Mekanik pada kompetensi menggunakan perkakas tangan untuk siswa kelas $\mathrm{X}$ jurusan Teknik Pemesinan di SMK Negeri Kulon Progo tahun pelajaran 2014/2015.

\section{SIMPULAN}

Penelitian ini memberi kesimpulan bahwa dengan menggunakan metode Problem 
Based Learning dalam pembelajaran Teknologi Mekanik siswa pada kompetensi menggunakan perkakas tangan siswa kelas X jurusan Teknik Pemesinan di SMK Negeri Kulon Progo dapat meningkatkan kemandirian dan hasil belajar siswa. Hal ini dapat dilihat dari nilai tes memenuhi kriteria ketuntasan minimal (KKM) sebelum tindakan sebesar $25 \%$ dan setelah tindakan sebesar $70 \%$; mampu bertanggung jawab atas permasalahan yang ada sebesar $37 \%$ dan sesudah tindakan sebesar 72\%; mampu disiplin dalam proses belajar mengajar sebesar $32 \%$ dan setelah tindakan sebesar $67 \%$, dan mampu aktif dan kreatif sebelum tindakan sebesar 14\% dan setelah tindakan sebesar $65 \%$.

\section{DAFTAR RUJUKAN}

Aqip, Zaenal. 2009. Penelitian Tindakan Kelas. Bandung: Karma Widya

Cendikia Rakhmad Darmawan. 2014. PeningKatan Kemandirian dan Hasil Belajar Matematika melalui Strategi Pembelaja- ran Problem Based Learning (Naskah Publikasi).Solo: FKIP UMS

Haris, Mudjiman. 2007. Belajar Mandiri. Solo: UNS Press

Moeloeng, Lexy J. 2006. Metode Penelitian Kualitatif. Bandung: PT. Remaja Rosdakarya

Nuraini, Siti. 2009. Profil Kemandirian Belajar Siswa SMK (Studi kearah Pengembangan Program Bimbingan Belajar Siswa). Bandung: Skripsi PBB FIP

Suharsimi, Arikunto. 2011. Prosedur Penelitian Suatu Pendekatan Praktek. Jakarta: Rineka Cipta

Sutama.2010. Penelitian Tindakan. Semarang: Citra Mandiri Utama 